\title{
実験および有限要素解析による自動車車体の構造ヒステリシス発生メカニズム
}

\author{
河内 毅*1，栗山 幸久 ${ }^{* 2}$ ，鈴木 克幸*2
}

\section{Experiments and finite-element-method analyses for mechanism of structural hysteresis of the vehicle body}

\author{
Takeshi KAWACHI ${ }^{* 1}$, Yukihisa KURIYAMA*2 and Katsuyuki SUZUKI*2 \\ ${ }^{*}$ Nippon Steel \& Sumitomo Metal Corporation \\ 20-1 Shintomi, Futtsu-shi, Chiba 293-8511, Japan \\ ${ }^{* 2}$ Research into Artifacts, Center for Engineering, The University of Tokyo \\ 5-1-5 Kashiwanoha, Kashiwa-shi, Chiba 277-8568, Japan
}

Received: 1 February 2018; Revised: 17 April 2018; Accepted: 29 May 2018

\begin{abstract}
In order to clarify the mechanism of the vehicle body hysteresis affecting "rigidity feeling", one of the driver's sensory evaluation in the driving test, the influence of friction acting on spot welding flanges on hysteresis, which is drawn by the displacement-load diagram of double-hat-shaped parts assembled by spot welding under static or relatively slow deformation, is experimentally and numerically evaluated. The hysteresis of two specimens, one has the contact around R-tangent of flanges and the other has it around edge, are compared and it is confirmed that the former type has larger hysteresis than the latter. The hysteresis is evaluated by the friction loss which is energy dissipation generated only by friction on the surfaces of the spot welding flanges. The loss calculated by the finite-element-method (FEM) with the contact and friction between two flange surfaces opposing each other has good agreement with that measured by the experiment. Additionally, by studying the detail of the relative slip and friction force distribution on the surface of two flanges obtained by the FEM analyses, the difference in hysteresis of two specimens and the cause of the friction loss are discussed.
\end{abstract}

Keywords : Vehicle body, Hysteresis, Rigidity feeling, Friction loss, Friction, Spot welding flange

1. 緒言

近年, 自動車軽量化に対する要求が厳しさを増す中，アルミニウム等の低密度金属や炭素繊維強化型プラスチッ ク（CFRP）等の樹脂を自動車の車体やシャシ部品に適用することで軽量化を達成する自動車が複数の自動車メー カで製造・販売されている。一方，高強度かつ薄手の鉄鋼材料（ハイテン材）の適用も進み，高価な低密度金属 や樹脂を使用せずとも軽量化と衝突安全性の両立を達成する自動車も非常に多い. 単なる薄手八イテン材への材 料置換は, 車体剛性を低下させることになり，車両の運動特性（操縦安定性や乗り心地）を低下させるため（椎葉 他，2013，嶋中他，2009，冨岡他，2007, 内山他，2015）, 車体構造や車体を構成する部品の接合を工夫するこ とによって車体剛性を高める取組みが多く報告されている（嶋中他，2009，冨岡他，2007）。

しかし，車体剛性の高低とは無関係に，実走行試験におけるドライバによる「剛性感」や「操作と車両の動き の一体感」という官能評価によって，車の善し悪しが決められることがある．この官能評価に関係して，車体の

No.18-00063 [DOI:10.1299/transjsme.18-00063], J-STAGE Advance Publication date : 6 June, 2018

*1 正員，新日鐵住金（株）（厂293-8511 千葉県富津市新富 20-1）

*2 正員, 東京大学 人工物工学研究センター（テ277-8568 千葉県柏市柏の葉 5-1-5）

E-mail of corresponding author: kawachi.a5q.takeshi@jp.nssmc.com 
ねじり剛性のヒステリシス（ねじり変形の位相の遅れ）が大きいと, ドライバは「ハンドル操作と車両の動きの 一体感がない」と感じるという報告が自動車メーカよりなされている（嶋中他，2009）。この報告においては, 上 記ヒステリシスの発生要因としてスポット溶接部の塑性変形を挙げている.

一方で, 弾性変形の範囲であるが, 車体剛性の非線形性が大きい, たとえば, 車体ねじり剛性について, ねじ りトルクの上昇に従い車体剛性が徐々に低下する現象が大きいと, 同程度のねじり剛性を持っていたとしても操 縦安定性の官能評価が悪化するという報告がなされている（熊本他, 2017）。この報告では, 車体の一部を抽出し た部分構造体を対象に, 走行中に車体にかかる荷重によって抽出した部位に生じる変形を再現する準静的繰返し 載荷実験において, 与える荷重と荷重点変位の履歷が描く線図がヒステリシスループを描き非線形性を示すこと を確認し，板間接触摩擦を考慮した有限要素法（以下, FEM）数值解析モデルを用いた弾性構造解析によって実 験と同様の非線形性が再現されることを示している. 実験と数值解析の比較から, 非線形性が車体を構成する複 数の部品の相対する溶接フランジ（以下, フランジ）における板間接触摩擦による影響であると結論付けている. さらに, 車体の一部（ドア開口部等）のフランジの板間に構造接着剂を適用することで, 車体剛性の非線形性が 低減し, 繰返し操舵における車両重心位置のヨ一速度（地面に垂直方向軸回りの回転速度）のピークが増大する ことを数值解析によって確認している. また, 構造接着剤を付与した車体を用いた走行試験において, ドライバ の官能評価值が向上することも報告している．この報告では，スポット溶接ナゲット外周から板厚程度の円環状 の領域において接触が生じているとし, 他の領域にはフランジ間に空隙が存在しているとしたモデルを採用して いる. しかし, スポット溶接が施工される二部品の接合面は設計上では互いに平行であっても, 実際にプレス成 形される部品はスプリングバックによって設計図面形状からずれが生じるため, 成形直後に互いに非平行な接合 面をスポット溶接ガンで強制的に接触させながら溶接することになる（吉田他, 2012）。したがって, 実際の自動 車車体では, フランジの一部において, 前述の熊本らの報告で言及されているナゲット外周に隣接する円環状部 分よりも広い範囲において部品同士の接触が生じ得る. また, その接触領域は, 上記円環状部分よりもナゲット から離れているため拘束を受けにくく, より大きい相対滑りが生じる可能性がある. そのため, 実際の自動車車 体を構成する部品では, 熊本らが想定した領域以外での接触が原因となるヒステリシスが発生する可能性がある.

上記のようなスプリングバックを模擬した形状のハット部品二つをスポット溶接し，フランジ面に接触領域を 持つダブルハット試験体を用い, 接触摩擦によるエネルギ損失を摩擦損失エネルギとして, 摩擦によるヒステリ シスを実験的に確認する報告がなされている（河内他，2017）。河内らは，フランジ面において強い接触を生じる 試験体と接触がほとんどない試験体を用い, せん断曲げ荷重を繰り返し与えた際の荷重と変位の履歴から損失エ ネルギを算出している，二つの試験体の損失エネルギの差分を評価することで試験機を構成する部品が原因とな る損失エネルギを除去し, ダブルハット部品の摩擦損失エネルギを評価している. また, 荷重の変化速度および 最大荷重をパラメータとした試験により，摩擦損失エネルギの荷重速度および最大荷重に対する影響を見積もり， 荷重速度をゼロに漸近させた摩擦損失エネルギを静的特性として静荷重において生じるヒステリシスと対応付け ている.また, 摩擦損失エネルギの最大荷重と荷重速度に対する依存性について, ばねーダンパの簡易物理モデ ルを用い説明している.しかし, 実際の摩擦面において生じる現象を実験的アプローチのみによって明確にする ことは困難であり, 数值解析等を利用した現象解明が必要である.

本研究では, 上記の河内ら（河内他，2017）の報告において示される摩擦損失エネルギ測定方法に従い, フラン ジ面において強い接触が生じるように成形した二つの部品を組み立てたダブルハット試験体を用い片持ち梁曲げ 実験を行い, フランジ面内の接触位置の違いによって生じる摩擦損失エネルギの差を評価する. さらに, 同一形 状モデル，同一境界条件による FEM 数值解析を実施し，フランジ間に接触を有するダブルハット試験体における ヒステリシスが摩擦によるもであることを確認する．また，上記の実験において試験体に負荷されるせん断力と 曲げモーメントについて考察し, 二つのハット部品のフランジの相対変位が部材全体のせん断変形によるもので り, 曲げモーメントはフランジの相対変位を生じさせない, つまり, 摩擦損失を生じさせないことを上記の FEM モデルを用いた解析によって示す，さらに，接触位置の差によって生じるヒステリシスの差について考察する. 


\section{2. 実験}

\section{$2 \cdot 1$ 試験体形状と試験機構成}

試験体は，図 1 に示すように，板厚 $t_{\mathrm{S}}=1.4 \mathrm{~mm}$ ，長さ $L=293 \mathrm{~mm}$ の引張強度 $440 \mathrm{MPa}$ 級鋼板を曲げ加工によっ て成形した二つのハット型部品をフランジにおいて片側 8 か所を溶融ナゲット径 $6 \mathrm{~mm}$ (狙い), ピッチ $p_{\mathrm{SW}}=35 \mathrm{~mm}$ でスポット溶接し，その両端に $B_{\mathrm{P}} \times B_{\mathrm{P}} \times t_{\mathrm{P}}=200 \mathrm{~mm} \times 200 \mathrm{~mm} \times 15 \mathrm{~mm}$ の寸法を持つ厚鋼板をアーク溶接によっ て接合する，ダブルハット試験体（specimen）である，上部の厚鋼板を連結端板（connecting plate），下部を固定 端板（base plate）と呼ぶ. 両端板溶接後に上下端面に機械加工による切削を施し，端板と連結治具およびベース 治具との接合面における平滑および二つの端面の平行を確保する. 図 2 に示すように試験体の断面形状は三種類 あり，フランジをスポット溶接する前にフランジ同士が平行になるよう成形した試験体 A（specimen-A），フラン ジ面が R 止まりからエッジに向かって隙間が広がるように成形した B（specimen-B），および，試験体 B のフラン ジ形状とは反対に R 止まりからエッジに向かって隙間が狭まるように成形した C (specimen-C) である. 試験体 $\mathrm{B}$ および C は, 溶接ガンの圧下力でフランジを押さえつけながら溶接するため, 試験体 $\mathrm{B}$ では $\mathrm{R}$ 止まり, 試験体 Cではエッジ付近においてフランジが互いに強く接触することになる．河内らの報告（河内他，2017）にある試 験体 B は，自動車車体を構成する部品のプレス成型工程において生じるスプリングバックによって，二つの部品 の溶接フランジ面が平行にならないことを想定し， $\mathrm{R}$ 止まり近傍での接触を模したものである．これに加え，試 験体 C は，エッジ近傍において接触が生じるように組み付けられる場合を想定している．実際に溶接組み立てさ れた試験体 B において，板エッジから R 止まりに向かいフランジ間隔は狭まり，エッジ側から挿入する $10 \mu \mathrm{m}$ 厚 の隙間ゲージがフランジ中央部までしか入らないことが確認されることから， R 止まり近傍においてフランジ同 土が接触しているものと考えられる．試験体 Cにおいても，端板溶接前に試験体内部の $\mathrm{R}$ 止まり側から挿入する 隙間ゲージがフランジ中央部までしか入らないことが確認され，エッジ近傍においてフランジ同士が接触してい るものと考えられる。一方，試験体 $\mathrm{A}$ は，熱の影響によりスポット溶接点以外の部位が互いに遠ざかる変形が発 生し（須藤他，1982），スポット溶接点以外のフランジ間に $10 \mu \mathrm{m}$ 厚の隙間ゲージが挿入可能なことが確認され， ナゲット周辺以外のフランジのほぼ全域において接触が発生しない.

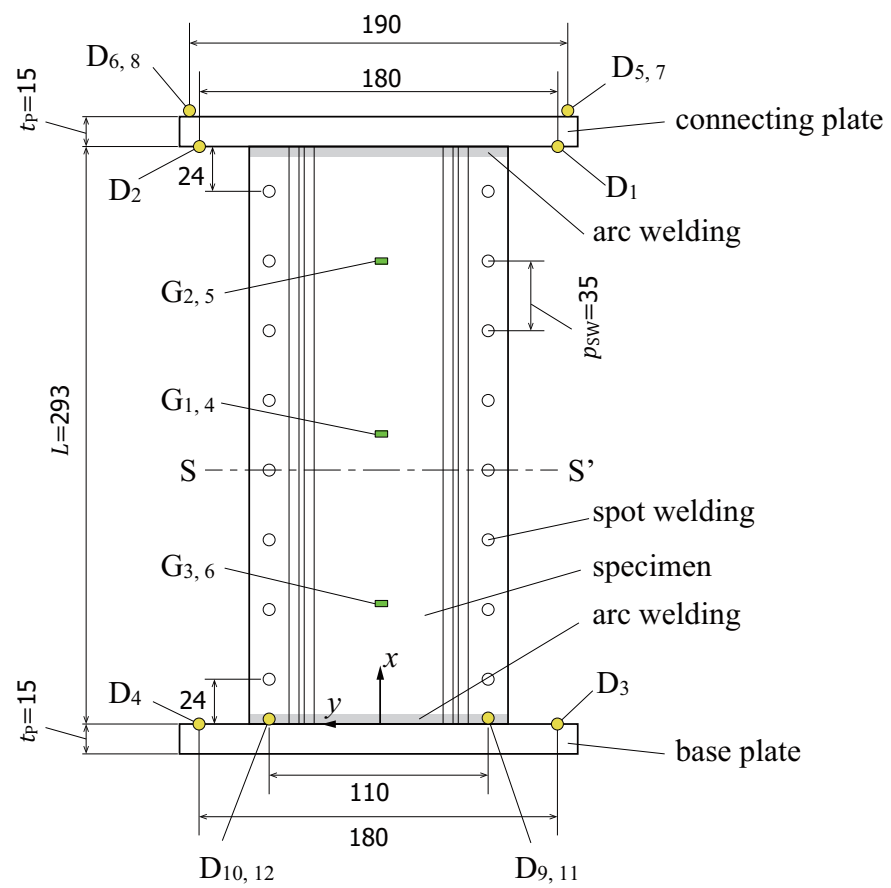

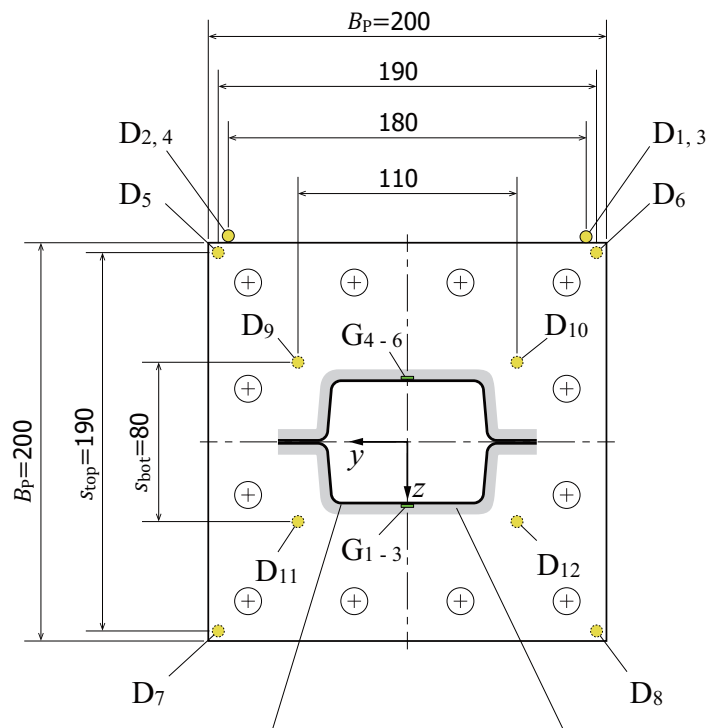

cross section of specimen arc welding

Fig. 1 the schematic side-view of the specimen (left) and top-view of connection and base plate (right) in units of millimeter. Circles noted by characters $\mathrm{D}_{i}(i=1,2, \cdots, 12)$ show the measurement points of displacement. Rectangles noted by characters $\mathrm{G}_{i}(i=1,2, \cdots, 6)$ show the measurement points of strain to estimate the contact force on the surface of flanges (refer to section $4 \cdot 1$ ). 


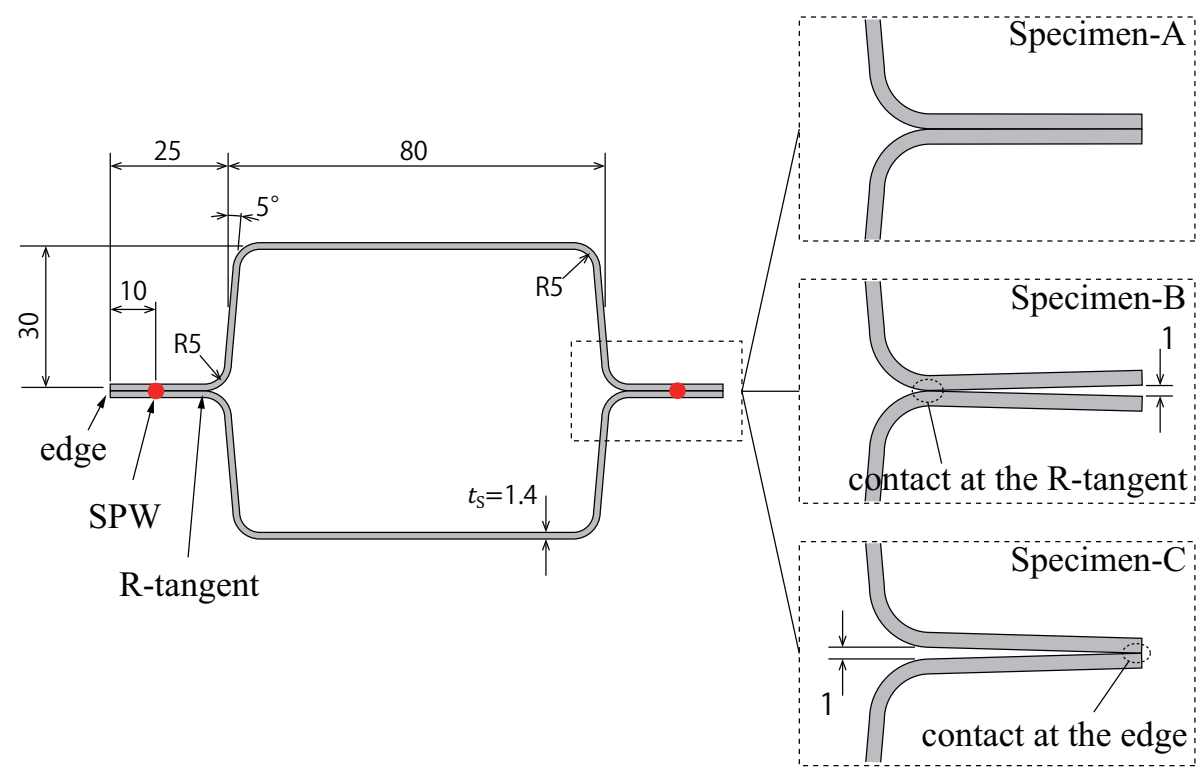

Fig. 2 the shapes of cross section of specimens at the section of S-S' in Fig. 1. In right figure, the shapes of flanges before spot welding of each specimen-A, $-\mathrm{B}$ and $-\mathrm{C}$ are showed. The dimensions are in units of millimeter. Before spot welding, specimen-B and $-\mathrm{C}$ have a clearance between their two flanges at the location of spot welding. After spot welding, the flanges of specimen-B and -C have contact area around the R-tangents and the edges respectively.

上記に示す三種類の試験体を用いて接触によって生じるヒステリシスを測定するための試験機構成は図 3 に示 すとおりである. 試験体軸心が上下方向（ $x$ 軸，図 3 右図の上向きを正とする）となるように設置し，スクリュー ジャッキ (screw jack) の稼働方向は水平方向（ $z$ 軸, 図 3 右図の左向きを正とする $)$ でフランジ面鉛直方向とする. 試験体の固定端版を $y z$ 面に水平な定盤に治具（base jigs）を介して固定し，連結端板に球面ジョイント（spherical joint）を介してロードセル（load cell）に接合される連結治具（connecting jig）をボルトで固定する. 球面ジョイ ント中心（以下，荷重点: load point）は無負荷状態において試験体断面の図心軸上に配置され，試験体と端板の溶 接線からの距離は $l=83 \mathrm{~mm}$ である. その他, 本試験において使用するロードセルや変位計等の使用機器および構 成は，河内らの報告（河内他，2017）と同様である.

試験体にはロードセルによって荷重值が計測されるせん断力が連結端板を介して $z$ 軸方向（フランジ面垂直方 向）に付与される片持ち梁せん断曲げ条件において，フランジのほぼ全域で接触摩擦がない試験体 A とフランジ 面内で強い接触摩擦を生じる試験体 $\mathrm{B}$ および $\mathrm{C}$ を比較することで鋼板の接触摩擦によって生じる摩擦損失エネル ギを計測する.

\section{$2 \cdot 2$ 荷重軸線上変位の定義}

図 1 に示す, 連結端板下面高さにおける二点 $\mathrm{D}_{1,2}$, および, 固定端板上面高さにおける二点 $\mathrm{D}_{3,4}$ の $z$ 軸方向変 位を $d z_{i}$, 連結端板上面と固定端板上面における八点 $\mathrm{D}_{5-12}$ の $x$ 軸方向変位を, $d x_{i}$ とする ( $i$ は, 測定点番号) . これらの計測される変位から, 試験体上端たわみ量 $d_{\mathrm{top}}$, 試験体下端たわみ量 $d_{\mathrm{bot}}$, 連結端板 $y$ 軸回り回転角 $\theta_{\mathrm{top}}$, および，固定端板 $y$ 軸回り回転角 $\theta_{\mathrm{bot}}$ を，

$$
\begin{aligned}
& d_{\mathrm{top}} \equiv \frac{d z_{1}+d z_{2}}{2} \\
& d_{\mathrm{bot}} \equiv \frac{d z_{3}+d z_{4}}{2} \\
& \theta_{\mathrm{top}} \equiv \arctan \frac{-d x_{5}-d x_{6}+d x_{7}+d x_{8}}{2 s_{\mathrm{top}}} \\
& \theta_{\mathrm{bot}} \equiv \arctan \frac{-d x_{9}-d x_{10}+d x_{11}+d x_{12}}{2 s_{\mathrm{bot}}}
\end{aligned}
$$



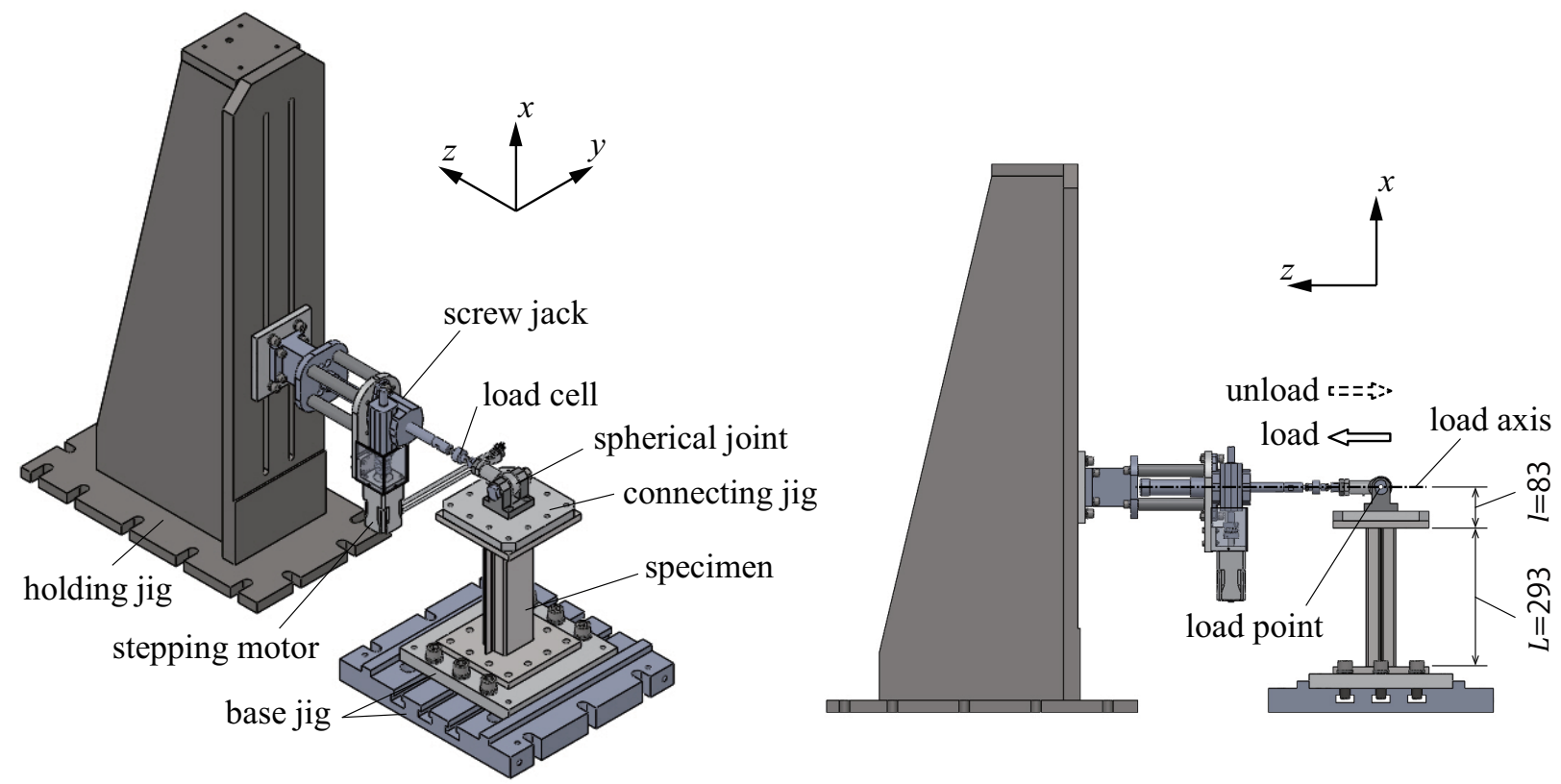

Fig. 3 the structure of measurement system (left: iso-view, right: side-view). The load axis and the centroid axis of specimen are parallel to $z$ - and $x$-axis, respectively. The normal vector of flange surface of double-hat specimen is parallel to $z$-axis.

と定義する。ここで， $s_{\mathrm{top}}=190 \mathrm{~mm}$ は二点 $\mathrm{D}_{5,7}$ ，または， $\mathrm{D}_{6,8}$ 間の距離，および， $s_{\mathrm{bot}}=80 \mathrm{~mm}$ は二点 $\mathrm{D}_{9,11}$ ，ま たは， $\mathrm{D}_{10,12}$ 間の距離である，さらに，端板や連結治具を剛体とみなし，固定端板の変形による影響を除外した荷 重点の変位 $\delta$ を, 式（1）に定義される值を用い,

$$
\delta \equiv d_{\mathrm{top}}-d_{\mathrm{bot}}+l \theta_{\mathrm{top}}-(L+l) \theta_{\mathrm{bot}}
$$

と定義し，この変位とロードセルによって測定される荷重の変化からヒステリシスを算出する.

\section{$2 \cdot 3$ 試験条件}

試験体 $\mathrm{A} ， \mathrm{~B}$ ，および，Cにおいて，ステッピングモータを制御し最小荷重が得られる位置を試験開始点とし， 最大荷重に至るまでステッピングモータの回転角を時間とともにほぼ直線的に変化させ, 最大荷重に達したとこ ろで 2 秒間保持する. 続いて, 最小荷重に至るまで時間とともにほぼ直線的に変化させ，最小荷重に達したところ で 2 秒間保持する.これを 1 サイクルとして, 複数（4～6）サイクルを連続して繰り返す. 最大荷重 $P$, および, 荷重速度 $\dot{F}$ を，表 1 に示す 6 ，および， 9 水準で実施する．なお，荷重ゼロ点付近におけるアクチュエータの遊び の影響を除外するため，常に正の荷重がかかるよう，最小荷重は， $0.01 \mathrm{kN}$ とする．最大，および，最小荷重前後 においては，0.01 sec で所定の荷重速度になるように加減速させる.

Table 1 the test conditions for the maximum load and load rate.

\begin{tabular}{ll|rrrrrrrrrr}
\hline Maximum load & $P$ & 0.25, & 0.5, & 0.75, & 1.0, & 1.25, & 1.5 & & & {$[\mathrm{kN}]$} \\
\hline Load rate & $\dot{F}$ & 0.1, & 0.2, & 0.4, & 0.8, & 1.2, & 1.6, & 2.0, & 2.4, & 3.2 & {$[\mathrm{kN} / \mathrm{sec}]$} \\
\hline
\end{tabular}




\section{3. 試 験 結 果}

\section{$3 \cdot 1$ 摩擦損失エネルギ測定結果}

各試験体の損失エネルギ $E_{\mathrm{S}}$ 添字（S は，試験体名である $\mathrm{A}, \mathrm{B}$ または $\mathrm{C}$ を示す）は，荷重一荷重点変位線図に おけるヒステリシスループによって囲まれる面積のサイクル平均（第 2 サイクル以降， $N_{\text {cycle }}$ 回の繰り返し）,

$$
E_{\mathrm{S}}=\frac{1}{N_{\text {cycle }}} \oint F \mathrm{~d} \delta
$$

と定義され, 各荷重および荷重速度条件において算出される. 式（3）で算出される試験体 B ルギと試験体 $\mathrm{A}$ の損失エネルギの差である摩擦損失エネルギ $E_{\mathrm{Bf}}$, および, $E_{\mathrm{Cf}}$ は,

$$
E_{\mathrm{Sf}}=E_{\mathrm{S}}-E_{\mathrm{A}}
$$

によって算出される（添字 S は，B Bたは C）。式（4）で定義される摩擦損失エネルギの計測結果を最大荷重ご とに整理し，図 4 に示す. ややばらつきがあるものの，試験体 $\mathrm{B}$ および $\mathrm{C}$ ともに破線で示す近似のように，最大 荷重および荷重速度の上昇に伴い摩擦損失エネルギが増加する。また，荷重速度ゼロの外挿点において，摩擦損 失エネルギは正值を持つ. 試験体 B と C について比較すると, 試験体 B の損失エネルギはいずれの試験条件にお いても試験体 $\mathrm{C}$ の損失エネルギより高い.この結果から，ダブルハット試験体のフランジ面内において，エッジ 側での接触よりも R 止まり側で接触する方が摩擦を起因とする損失が大きいことがわかる.
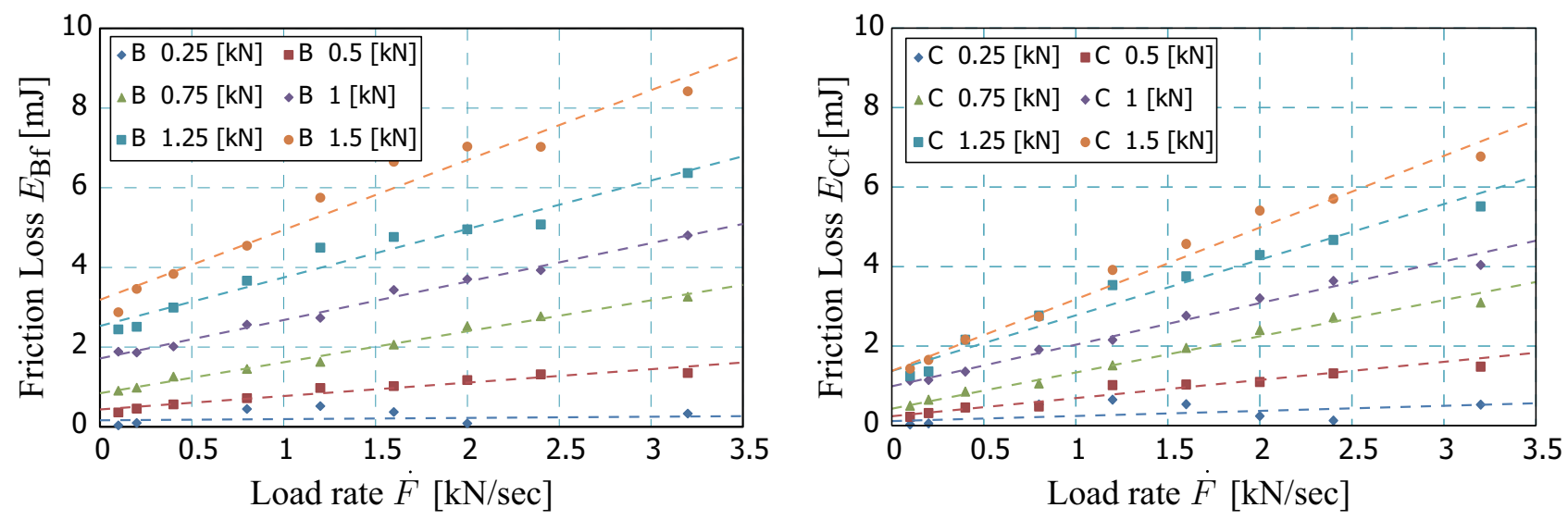

Fig. 4 the friction loss of specimen-B and -C. The horizontal axis is the rate of load $\dot{F}$ in units of [kN/sec] and the vertical axis is the friction loss $E_{\mathrm{Bf}}$ or $E_{\mathrm{Cf}}$ in units of millijoule. All plots are distinguished by maximum load and the dash-lines are straight approximate by load rate on each maximum load level.

\section{$3 \cdot 2$ 摩擦損失エネルギの静的特性}

図 4 に示すグラフにおいて, 低速度極限值として荷重速度ゼロへの外挿点（近似直線の縦軸切片）を摩擦損失 エネルギの静的特性（以下, 静的特性） $E_{\mathrm{S} 0}$ とし, 図 5 に評価結果を示す. 試験体 B の静的特性はすべての最大荷 重条件において試験体 Cより高い結果を示す.

\section{4. 数 值 解 析}

\section{$4 \cdot 1$ 解析モデル}

前節で得られた二つの試験体における摩擦損失エネルギを有限要素法（FEM）を用いて再現することを試みる. 数值解析は, 汎用 FEM ソフトABAQUS/Standardによる接触を考慮した静的陰解法非線形弾性解析であり, 試験 体はソリッド要素（八節点六面体線形要素 C3D8，または，六節点五面体線型要素 C3D6）によって表現される. 


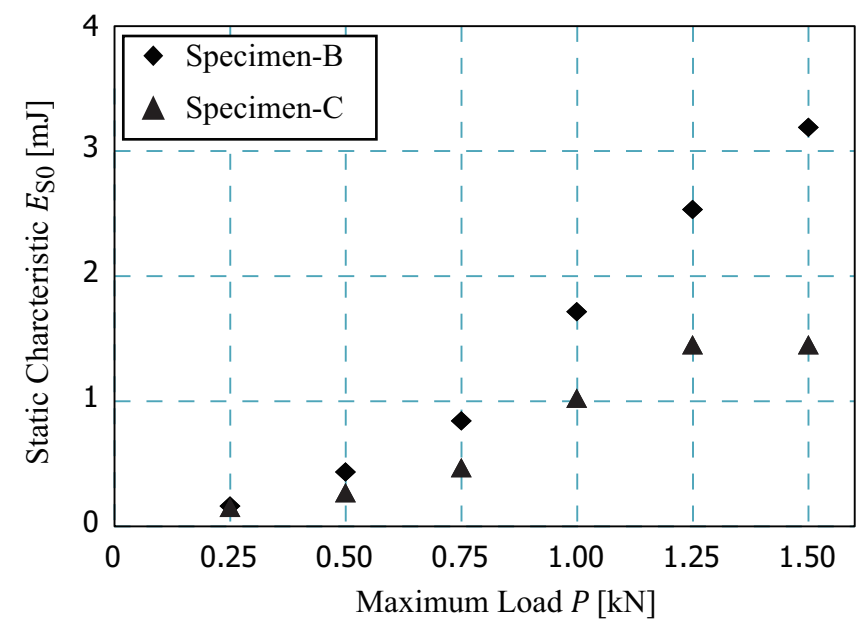

Fig. 5 the static characteristic of friction loss. The horizontal axis is the maximum load in units of kilonewton and the vertical axis is the static characteristic of friction loss determined as friction loss-axis intercept on each maximum load in figure 4 in units of millijoule for specimen B (diamond-marker) and C (triangle-marker). The dash- and solid-line mean second-order approximate passing through the origin in gradient zero for specimen-B and $-\mathrm{C}$ respectively.

試験体を静的に変形させる状態を扱うものとし，3.2 節で得る静的特性を再現することを目的とする. 図 6 に示す ように, 図 2 に示す試験体 A（specimen-A）の断面を持つ二つのハット部品から成り立ち，それらはフランジ接 触面に対して形状および節点座標が対称である. 二つのハット部品はスポット溶接部において節点を共有するこ とで結合されている（図 6 の中央下の図を参照）。また，すべて Young 率 $206 \mathrm{GPa}$, Poisson 比 0.3 の等方物性材 料とする.

フランジが非平行な状態から強制的にスポット溶接する過程を数值解析等でシミュレートすれば，試験体 B お よびCのフランジ面接触状態（接触範囲や接触圧分布等）をある程度正確に予測することができる.しかし，ス ポット溶接ガンによる拘束, 通電による昇温, 鋼板の溶融, 溶融部の凝固, 冷却, スポット溶接ガンの開放といっ た複雑な工程を扱い, それらの過程における物性值を正確に計算に反映させることは, 膨大な数值解析コストを 要求する.ここでは, フランジ面の限られた領域に互いに反発しあうような初期表面圧力を与え, 試験体 B およ びCのフランジ面における接触を表現し，それぞれ，モデル B およびC（model-B および-C）とする.

摩擦損失エネルギ測定後の試験体を各ハット部品に解体し，そのときにハット部品表面に生じるひずみを計測す ることで，フランジ面における接触力を推定することを試みる. 図 1 に示す試験体のハット部中央の 6 点 $\mathrm{G}_{1-6}$ に ひずみゲージを貼付し, 初期状態をひずみゼロとして, 上下の端盤およびすべてのスポット溶接部を切削し, 二 つのハット部品に解体されるときに計測される試験体幅方向（ $y$ 軸方向）の 6 点のひずみの平均值を $\varepsilon_{\mathrm{S}}$ とし（添 字 $\mathrm{S}$ は, $\mathrm{B}$ または $\mathrm{C}$ であり, 試験体名を意味する), 図 7 に示す梁曲げモデルも用いて考えると, 試験体長手方 向単位長さあたりの接触力 $\lambda_{\mathrm{S}}$ は,

$$
\lambda_{\mathrm{B}}=-\frac{E t^{2}}{3 d} \varepsilon_{\mathrm{B}}, \quad \lambda_{\mathrm{C}}=\frac{E t^{2}}{3 d} \varepsilon_{\mathrm{C}}
$$

となる.ここで, $E=206 \mathrm{GPa}$ は試験体を構成する鋼板の Young 率, $t=1.4 \mathrm{~mm}$ は試験体の板厚, $d=6.75 \mathrm{~mm}$ は スポット溶接ナゲット中心から接触範囲の中心までの距離である. 式（5）と計測される平均ひずみによって定ま

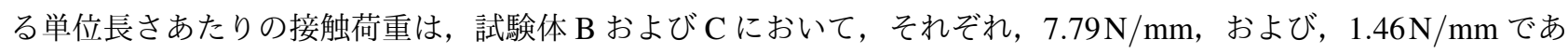
る. 試験体 $\mathrm{B}$ および $\mathrm{C}$ の接触範囲は，それぞれ，フランジ $\mathrm{R}$ 止まりおよびエッジ近傍のごく狭い範囲に限定され ると推定し, 数值解析モデルでは, 図 6 に示す幅 $(y$ 軸) 方向に $6.5 \mathrm{~mm}$ の範囲に, その面積積分が上記で算出し た接触力となるように図 8 に示す $(x=146.5 \mathrm{~mm}$ での分布を示す）面圧を与えた状態を初期状態として解析を進 める. また, $x$ 軸方向には均一分布面圧とする.

二つのハット部品のフランジ面において, 接触およびCoulomb 摩擦を考慮し, 鋼板同士の摩擦係数は, 経験的 に $\mu=0.1-0.2$ の範囲で設定し，また，相対滑り量や面圧には依存せず一定であるものと仮定する. 


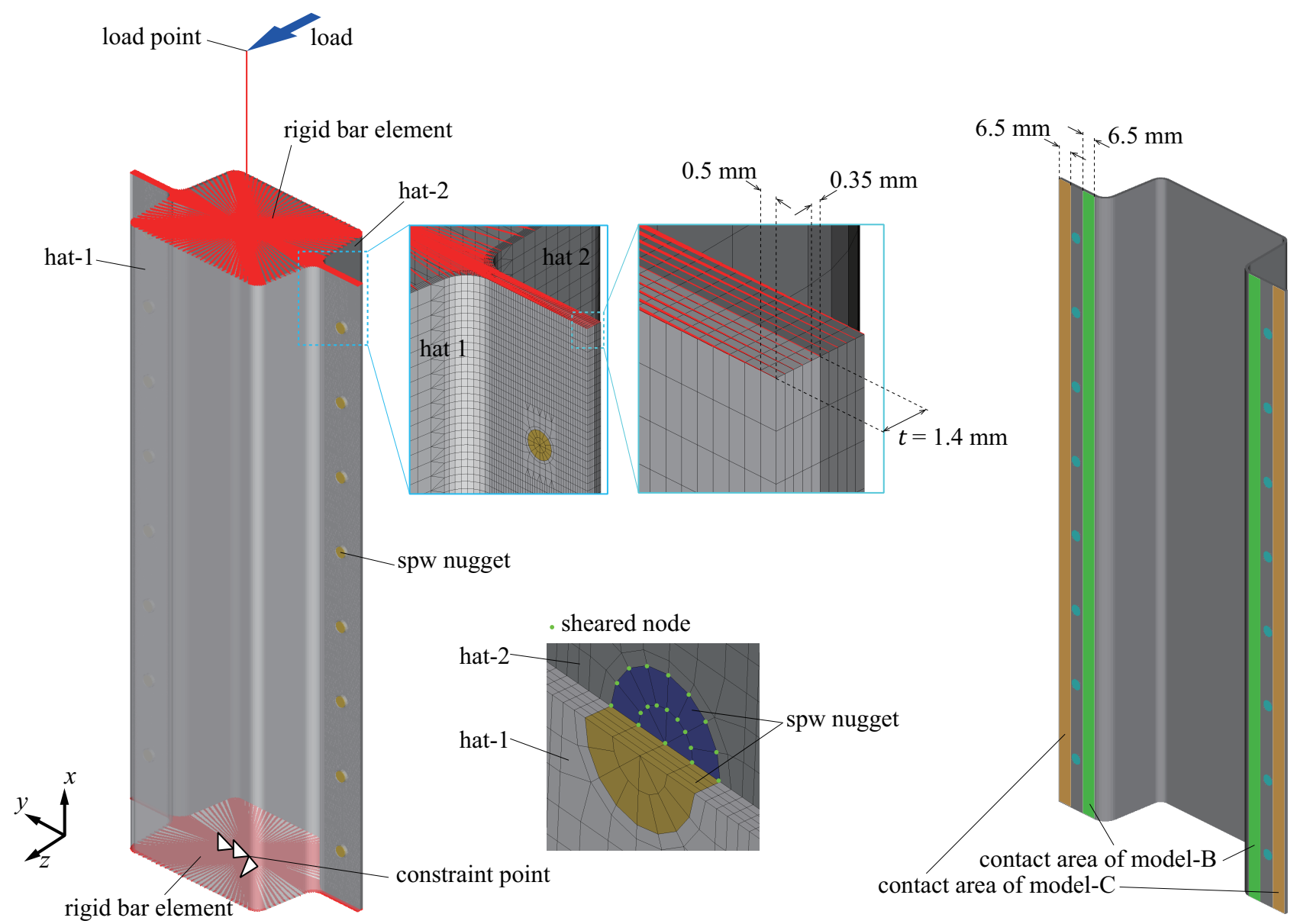

Fig. 6 the analysis model for Finite-Element-Method (FEM).The left image is whole figure of the model, three images in the middle are its enlarged views and the right shows contact regions on the flanges of model-B and $-\mathrm{C}$.

モデルの片端（ $x=0$ の断面）において, 全節点と断面中心 $(x, y, z)=(0,0,0)$ における節点を剛体梁要素（BEAM） でつなぎ，断面中心節点の全自由度を拘束することで固定点（constraint point）とする. 他端（ $x=293$ の断面）の 節点および球面ジョイント中心 $(x, y, z)=(376,0,0)$ における節点を断面中心 $(x, y, z)=(293,0,0)$ における節点と 剛体梁でつなぎ，球面ジョイント中心節点を荷重点（load point）として， $z$ 軸方向に荷重を与える荷重境界点とす る. 与える荷重は，ゼロから表 1 に示す最大荷重まで徐々に上昇，最大荷重からゼロまで徐々に低下させ，これ を 2 サイクル繰り返し, 解析の評価は, 第 2 サイクルのみを対象とする.

上記のモデルを用いて計算される摩擦によるヒステリシス再現を試みるが, 摩擦損失エネルギの大きさは, 実 験結果から, 外力によって系全体に与えられる最大のひずみエネルギに対して $1 \% に$ 満たないことが予想される. 数值解析の収束性（または安定性）を向上させるための数值減衰や, 接触面における摩擦の計算において固着時 （つまり，摩擦面に働くせん断力が静摩擦力を下回る状態）においても微小な相対変位を許容する弾性滑りといっ た数值解析上のテクニックの使用は，それ自体がヒステリシスの発生要因または削減要因になり，上記の微小な 摩擦損失エネルギに影響を及ぼすことが想定されるため，限定的である必要がある. 今回の試みでは，いくつか の試行解析の結果, 数值減衰のオプションは採用せず, 弾性滑りの許容距離 $d_{\mathrm{es}}$ を可能な限り小さくし（具体的に は, $d_{\mathrm{es}}=7.7 \times 10^{-6} \mathrm{~mm}$ とし)，解析の安定化と摩擦によるヒステリシスの再現を両立する. 弾性滑りによって蓄 えられるひずみエネルギは, 摩擦損失エネルギに比べて十分小さいことが要求されるが, このひずみエネルギの 最大值は，フランジ面における静止摩擦力と弾性滑り許容距離の積のオーダである. したがって, 上記の接触力 $2 L \lambda_{\mathrm{B}}=2 \times 293 \mathrm{~mm} \times 7.79 \mathrm{~N} / \mathrm{mm}=4565 \mathrm{~N}$ （接触領域は 2 か所であることを考慮）と摩擦係数 $\mu=0.2$ を用いると， 弾性滑りによって蓄えられる最大ひずみエネルギ $E_{\mathrm{es}}$ は, 
- Spot welding nugget

$\square$ Contact region of specimen-B

Contact region of specimen-C

Force by spot welding

Reaction force on contact surface

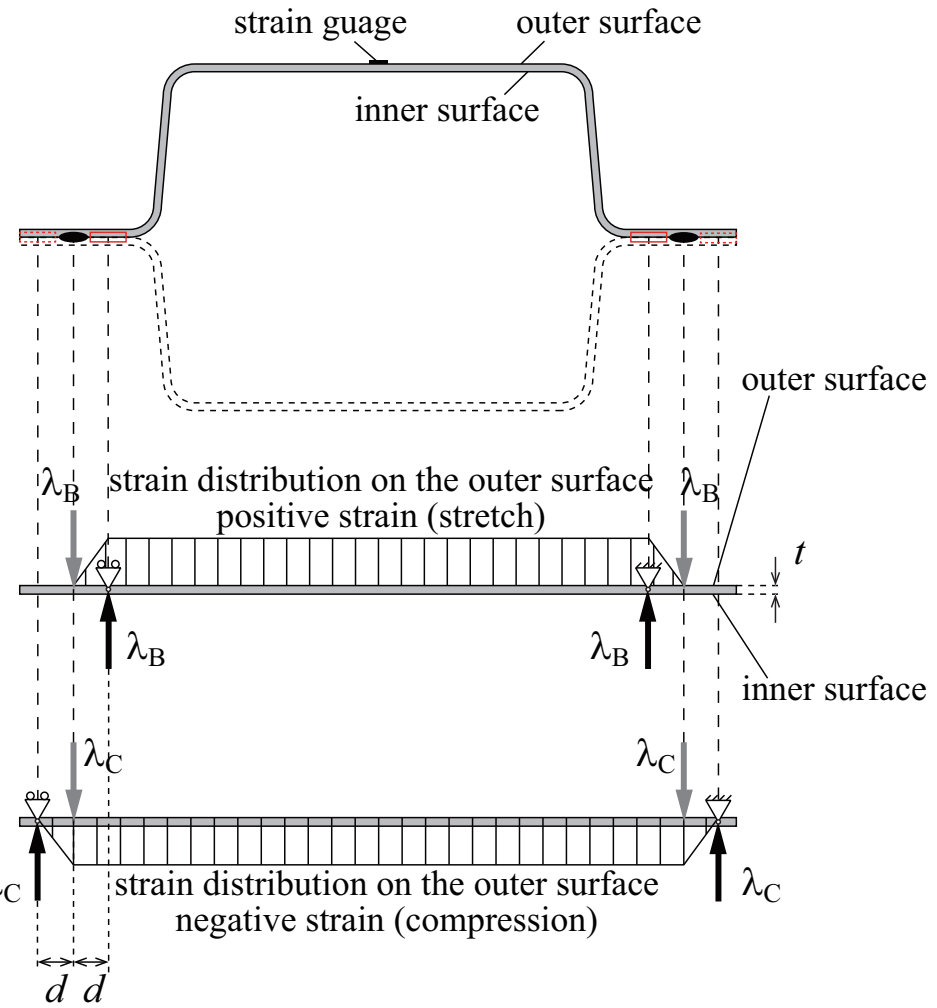

Fig. 7 the schematic image of the measurement of strain stored in specimens by the welding. The top figure shows the location of the strain gauge for measurement of the strain. The middle and bottom figure show the bending model to calculate the contact force for model-B and -C respectively.

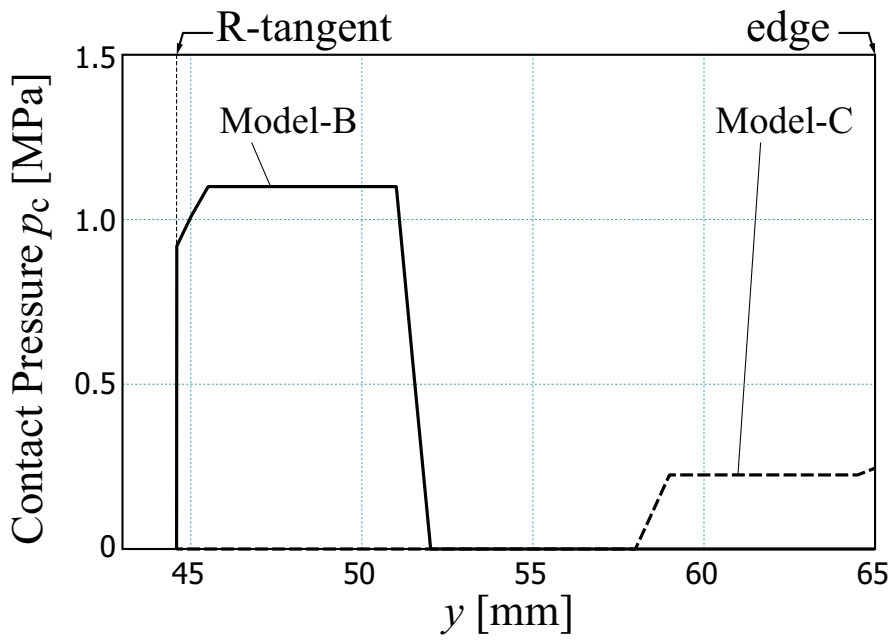

Fig. 8 the contact pressure distribution on the center of flanges. The horizontal axis is $y$ coordinate in units of millimeter and vertical axis is contact pressure in units of megapascal. The solid-line and dash-line are the pressure distribution for model-B and $-\mathrm{C}$ respectively.

$E_{\mathrm{es}} \sim 2 \mu L \lambda_{\mathrm{B}} d_{\mathrm{es}} \sim 7 \times 10^{-3}[\mathrm{~mJ}]$

となり，3.2 節で得られる摩擦損失エネルギの実測值の最小值（最大荷重 $0.25 \mathrm{kN}$ の条件）に対しても $5 \%$ 未満の オーダであり，弾性滑りにによる影響は小さいものと予想される. 


\section{$4 \cdot 2$ ヒステリシスループと静的特性}

$3 \cdot 1$ 節に示す実験と同様，荷重-変位線図におけるヒステリシスを評価する．実験では試験機が持つヒステリシス を差し引く作業を要するが, 数值解析ではそのような外乱を完全に除外できるため, 数值解析結果から得られる荷 重一変位線図で囲まれる面積を静的摩擦損失として評価する．今回の解析で計算される摩擦損失は小さく，荷重一 変位線図で描かれるヒステリシスループの幅は非常に狭く，視覚的な確認が難しい．そこで，荷重-変位線図にお ける平均傾きとして岡性を計算し, それらの平均值を $K_{\mathrm{S}}$ として, 変位 $\delta$ から荷重と剛性の比 $F / K_{\mathrm{S}}$ との差 $\delta_{\mathrm{Hys}}$,

$$
\delta_{\mathrm{Hys}}=\delta-\frac{F}{K_{\mathrm{S}}}
$$

をヒステリシス幅として定義する. 摩擦係数 $\mu=0.2$ において，このヒステリシス幅 $\delta_{\mathrm{Hys}}$ を横軸に，荷重 $F$ を縦 軸にとったグラフを図 9 に示す. 原点を開始点として紙面向かって右回りに変化が進む. 荷重ゼロから最大荷重に 至るまでがヒステリシスループの左上に, 最大荷重から荷重ゼロに至るまでが右下に相当する. モデル B および Cともに, 最大荷重を経て荷重がゼロになっても, 原点に戻らずヒステリシス幅は正の值を持ち, 変位が残留する 結果を得る。この点（starting point of 2nd cycle）から第 2 サイクルが開始し, 載荷途中から除荷完了まで第 1 サイ クルと同じ経路をたどる. モデル $\mathrm{B}$ の $P=0.25 \mathrm{kN}$ を除き, 第 2 サイクルのヒステリシスループは矩形状になる. 荷重ゼロからの載荷量, または, 最大荷重からの除荷量が, モデル B では約 $0.36 \mathrm{kN}$, モデル Cでは約 $0.15 \mathrm{kN}$ に 到達する付近で屈曲点（bend point）が現れ，ヒステリシスループの傾きが大きく変化する.
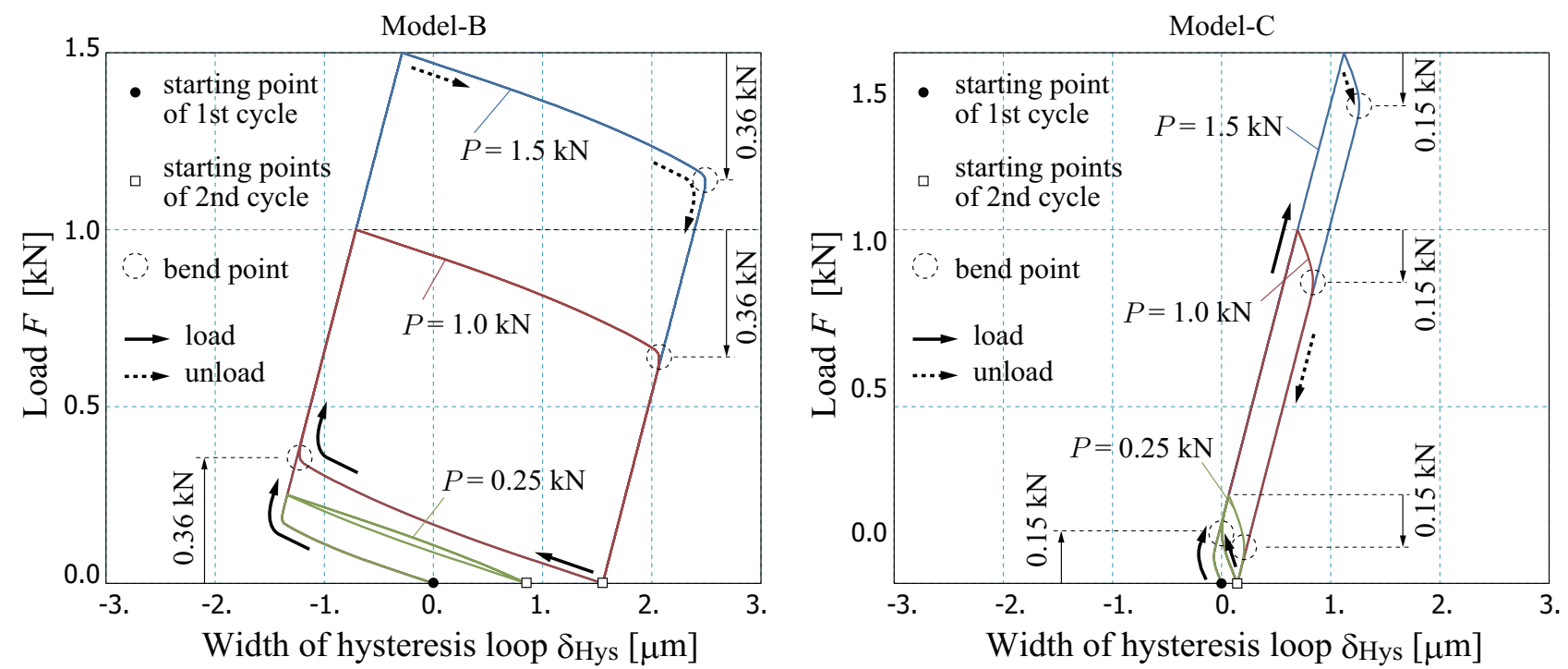

Fig. 9 the hysteresis loop of model-B (left) and -C (right) with maximum loads $P=1.5 \mathrm{kN}$ (blue), $P=1.0 \mathrm{kN}$ (red) and $P=0.25 \mathrm{kN}$ (green). The horizontal axis is the hysteresis width determined by equation (7) in units of micrometer and the vertical axis is the force on the load-point in units of newton. The dash-linecircles mean bend points.

図 9 の線図において第 2 サイクルで囲まれる面積が図 5 右に示される静的特性に相当し, 試験結果との比較と共 に図 10 に示す.上述したように, 数值解析では 2 つサイクルの荷重変動を与えているが，摩擦損失の計算には 初期状態の影響を除外するために第 2 サイクルを用い，式（3）に従って算出する. 最大荷重の上昇に伴い静的特 性も上昇し, モデル C に比べて B の方が高い結果が得られ，本数值解析によって実験で得られるヒステリシス現 象を概ね表現できる. なお, 本数值解析では, 摩擦係数を $\mu=0.1-0.2$ の範囲で変動させるが, 数值解析で得られ る静的損失は摩擦係数にほぼ比例する。ここでは, 実験結果と定量的な一致度が最も高い $\mu=0.2$ を採用している. 


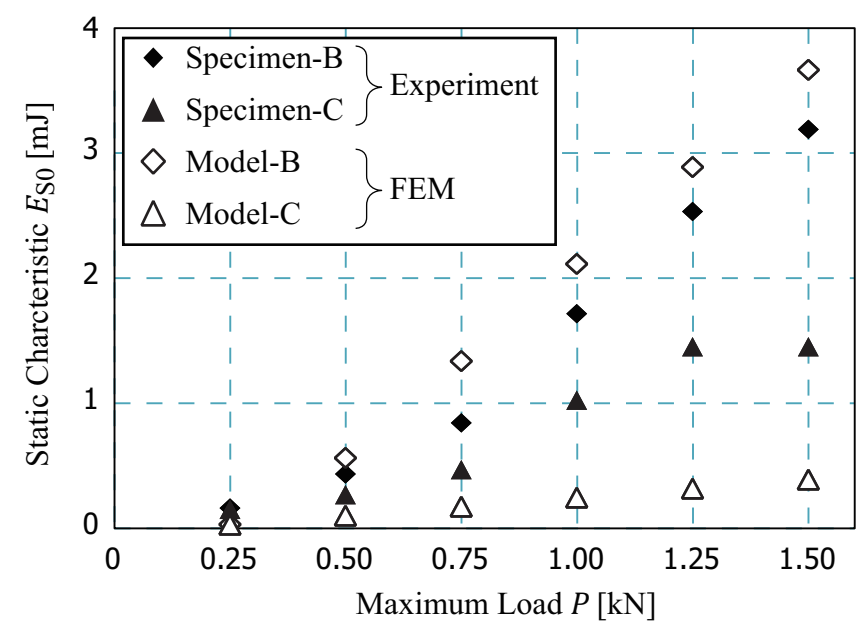

Fig. 10 the comparison of energy loss calculated by the FEM analysis and measured by the test mentioned in section 3.2. The horizontal axis is the maximum load in units of kilonewton and the vertical axis is the static friction loss in units of millijoule. The solid-diamond-, solid-triangle-, open-diamond- and opentriangle-markers mean specimen-B, specimen-C, model-B and model-C respectively.

\section{5. 考察}

\section{$5 \cdot 1$ 相対滑りの形態と摩擦力の分布}

摩擦によるエネルギ損失が生じるためには，摩擦力が作用する二つの接触面が摩擦面内において相対的に変位 を持つことが必要であり，モデル B および C の摩擦力および相対滑り分布，および，荷重変化におけるそ机ら分 布の変化について数值解析結果を分析し, 数值解析の荷重-変位線図におけるヒステリシスがフランジ間摩擦によ るものであることを確認し，さらに，摩擦損失の発生の原因と過程について考察する.

荷重点にせん断力を与えると, せん断力と曲げモーメントが付与される試験体または解析モデルはせん断およ び曲げ変形するが, 解析モデルにおいて, 荷重点に $y$ 軸回りモーメントを与え, 二つのハット部品にせん断力を 生じさせない条件で数值解析を実行すると, 両ハット部品のフランジ面に相対滑りが発生せず, 荷重（モーメン ト）-変位（変位角）線図にヒステリシスループは生じない。一方，荷重点の回転変位を拘束しながら $z$ 軸方向に 正の荷重を与えると，モデル下端および上端（ $x=0$ および $x=293 \mathrm{~mm}$ の断面）をそれぞれ $z$ 軸負および正の方 向にせん断する変形と同時に, ハット 1 および 2 (hat-1 および-2）をそれぞれ $x$ 軸正および負の方向にせん断す る変形が生じる。このせん断力によって，ハット 1 および 2 のフランジ面が，それぞれ $x$ 軸方向正および負の方 向に相対的に変位（相対滑り）する.二つのフランジ面間に接触および摩擦が存在すると, 相対滑りによってエ ネルギが消費されるため, 荷重-変位線図にヒステリシスループを生じさせることになる，以下において，フラン ジ面における相対滑りの形態と相対滑りに付随して生じる摩擦力分布を定量的に評価し, 摩擦によって生じる構 造ヒステリシスについて分析する.

最大荷重 $P=1.5 \mathrm{kN}$ の条件の第 2 サイクルにおいて, フランジ面上の四つの経路, 経路 1 から 4 (path-1-4）に 沿った二つのフランジ面の変位差の絶対值である相対滑り分布, および, ハット 1 のフランジ面にかかる摩擦によ るせん断応力（相対滑りが増加するときに生じる摩擦力を負とする）の分布を，また，フランジ面上の二つの点， 点 1 および 2 (point-1 および-2) における相対滑りおよび摩擦せん断応力の履歴を, モデル B およびCそれぞれ について図 11 に示す. $0 \mathrm{kN}$ (load) の第 2 サイクルの開始点から載荷し最大荷重に至るまで 5 荷重点, および, 最 大荷重から除荷し荷重ゼロに至るまでの 5 荷重点の計 9 荷重点（最大荷重点は共有）における分布を示す. 荷重 ゼロにおいても二つのフランジ面には，モデル B では $0.38 \mu \mathrm{m}$ ，モデル Cでは $0.077 \mu \mathrm{m}$ の相対滑りが残留してお り，摩擦によってモデル B では R 止まり周辺の相対滑りが，モデル Cではエッジ周辺の相対滑りが戻りきらない. また, 開始点から載荷しても, 低荷重域では二つのハット部品間に㗢くフランジ面を滑らせるようなせん断力が フランジ面間に㗢く摩擦力を越えることができず，モデル B では荷重が $0.25 \mathrm{kN}$ ，モデル Cでは荷重が $0.1 \mathrm{kN}$ に 到達しても，フランジ接触範囲（モデル B では R 止まり近傍，モデル Cではエッジ近傍）の相対滑り量はほとん ど変化しない. 荷重が十分に上昇するとフランジにかかるせん断力が静摩擦力に達することで相対滑りが変化し, 
その後は, 最大荷重に至るまで荷重増加量にほぼ比例して相対滑りも増加する. 最大荷重から除荷の過程に入る と, 開始点付近と同様に, 除荷量が小さい（荷重が最大值に近い）領域では, 弾性変形するハット部品が復元し ようとすることによってフランジ間に生じるせん断力が摩擦力を越えないため, 接触領域の相対滑り量にほとん ど変化はなく, 十分に除荷された状態になると相対滑り量が減少に転じる. 荷重がゼロに到達すると, 相対滑り, 摩擦せん断応力ともに, 開始点の状態に戻る. 結果, この各節点の摩擦力と相対滑り量の変化に生じる位相差が, 荷重変化と荷重点変位変化におけるヒステリシスの原因になる.

\section{$5 \cdot 2$ ヒステリシスループ形状に関する考察}

モデル B では載荷過程では 0.25 から $0.5 \mathrm{kN}$ の間, モデル Cでは 0.1 から $0.25 \mathrm{kN}$ の間において, 接触領域 (contact area）の全領域における摩擦力が最大静止摩擦力に到達し，それまでほとんど生じないフランジの相対滑りが急激 に大きくなる. 図 9 に示すヒステリシスループと比較すると, この状態の発生荷重が第 2 サイクルの載荷過程に おける屈曲点（モデル B: 約 $0.36 \mathrm{kN}$ ，モデル C: 約 $0.15 \mathrm{kN}$ ）に対応するものと考えられる. 屈曲点荷重に至るま では, 荷重増加に伴い接触領域の一部は相対滑りを開始するものの, 固着領域がその変位を抑制するため, 荷重 増加に対して荷重点変位の増加率は比較的小さい，屈曲点荷重を超えると最大荷重に至るまで接触面全面が滑る ため, 摩擦抵抗は一定になり, 荷重点変位の増加率が増大する. したがって, この点前後において, ヒステリシ スループの傾きが大きく変化することになる. 除荷過程においても, 最大荷重から 0.25 から $0.5 \mathrm{kN}$, モデル Cで は 0.1 から $0.25 \mathrm{kN}$ 除荷された点において全接触領域が滑り出し, ヒステリシスループに屈曲点（モデル B: 最大 荷重から約 $0.36 \mathrm{kN}$ 下, モデル C: 最大荷重から約 $0.15 \mathrm{kN}$ 下）が生じると考えられる. 屈曲点に到達する前に最 大荷重に達する条件では全接触領域の滑りが発生せず, 載荷および除荷過程において明確な屈曲点を持たない.

\section{$5 \cdot 3$ 摩擦力がなす仕事とヒステリシスの比較}

最大荷重 $P=1.5 \mathrm{kN}$ の条件におけるモデル B およびC のフランジ面接触領域内, 長手方向中央 $(x=146.5 \mathrm{~mm})$ 上の節点を例に, 摩擦力と相対滑り量の履歴を図 12 に示す. フランジ接触部における各節点に働く摩擦力ベクト ルと荷重点における荷重変化で生じる接触面との相対滑り増分ベクトルの内積の時間積分（図 12 のループで囲ま れる面積に相当する）の全接触面内節点における和が荷重変化の過程で摩擦力がなす仕事であるため, これを第 2 サイクルの開始点から終了点までで計算した結果を 4.2 節に示す静的摩擦損失と比較すると, すべての条件で $0.1 \%$ 未満の差という結果を得る. したがって, 荷重-変位線図に見られるヒステリシスループは, 数值解析の安定 性を得るための数值減衰の影響はなく, フランジ間摩擦によって生じたものであると確認される.

モデル Cで得られる摩擦損失は, 試験体 C の実測結果に比べて小さい. これは, 板エッジにおけるせん断端面 形状, 仮定した接触領域や摩擦係数を含めた摩擦モデルに原因があると考察する. 特に板エッジでは, 相対する フランジ面の食い込みが生じ, 見かけの摩擦係数に大きな影響を及ぼすことが予想される. しかし, 板エッジせ ん断端面形状を表現するためには, より細かいメッシュサイズが要求され, 計算コストを大幅に増大させること が予想されること, および, 変動する荷重環境にさらされる構造体の溶接フランジ面における摩擦がヒステリシ スの原因になり得ることが上記の議論によって確認されることから, 本論文では板エッジにおける詳細な摩擦挙 動については議論せず, 今後, 自動車車体等の大きな構造体のヒステリシス予測技術への展開を検討する.

\section{4 スポット溶接による影響}

図 11 の経路 4（path 4）に示すように，スポット溶接ナゲットは，節点を共有しているため相対滑りはあらゆる 条件においてゼロであり，その近傍もその拘束の影響を受けて相対滑りは小さい，このことは，スポット溶接近傍 における摩擦によって生じる損失が小さいことを示唆しており, 試験体 A の摩擦損失を無視できるものとした試 験の妥当性を裏付ける.

また，このスポット溶接による拘束は，フランジ面における相対滑りおよび摩擦力分布に影響を及ぼす．今回の 対象であるダブルハット試験体にせん断力を与える場合, 二つのハット部品が互いにフランジ面内を滑るように せん断変形するが，スポット溶接による拘束の外側であるエッジ部近傍は， R 止まり部近傍に比べてせん断変形が その拘束により抑えられる．モデル B および C のフランジ面接触領域（モデル B では， R 止まり $y= \pm 45 \mathrm{~mm}$ 近 傍, モデル Cでは, エッジ $y= \pm 65 \mathrm{~mm}$ 近傍）について比較すると, 相対滑り量, 摩擦力ともにモデル B の方が 
edge path-1 path-2 point-1 point-2 path-3 path-4 relative $\operatorname{slip} S_{\mathrm{c}}=\boldsymbol{S}_{\mathbf{1}}-\boldsymbol{S}_{\mathbf{2}}$

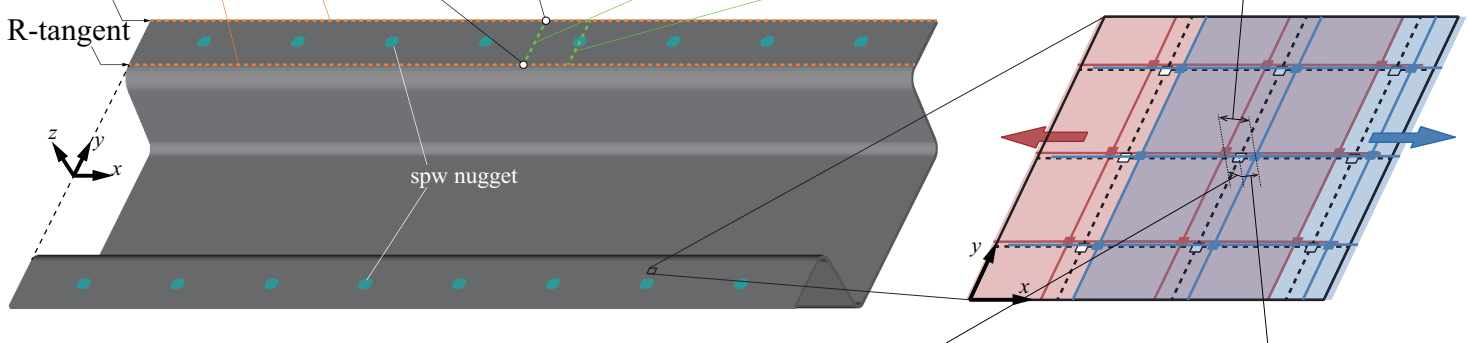

displacement of the node on hat-2 $\boldsymbol{S}_{\mathbf{2}}$ displacement of the node on hat-1 $\boldsymbol{S}_{\mathbf{1}}$

\begin{tabular}{|c|c|c|c|}
\hline$-0.00 \mathrm{kN}$ & & $-1.50 \mathrm{kN}$ & \\
\hline$-0.10 \mathrm{kN}$ & & $\cdots 1.40 \mathrm{kN}$ & \\
\hline$-0.25 \mathrm{kN}$ & load & $\cdots 1.25 \mathrm{kN}$ & unload \\
\hline$-0.50 \mathrm{kN}$ & & $\cdots 1.00 \mathrm{kN}$ & \\
\hline$-1.50 \mathrm{kN}$ & & $\cdots 0.00 \mathrm{kN}$ & \\
\hline
\end{tabular}

node and mesh on the contact surface of hat-1

+ node and mesh on the contact surface of hat-2

-.ị:-. node and mesh on the contact surface of original position

mesh deformation image on the contact surface
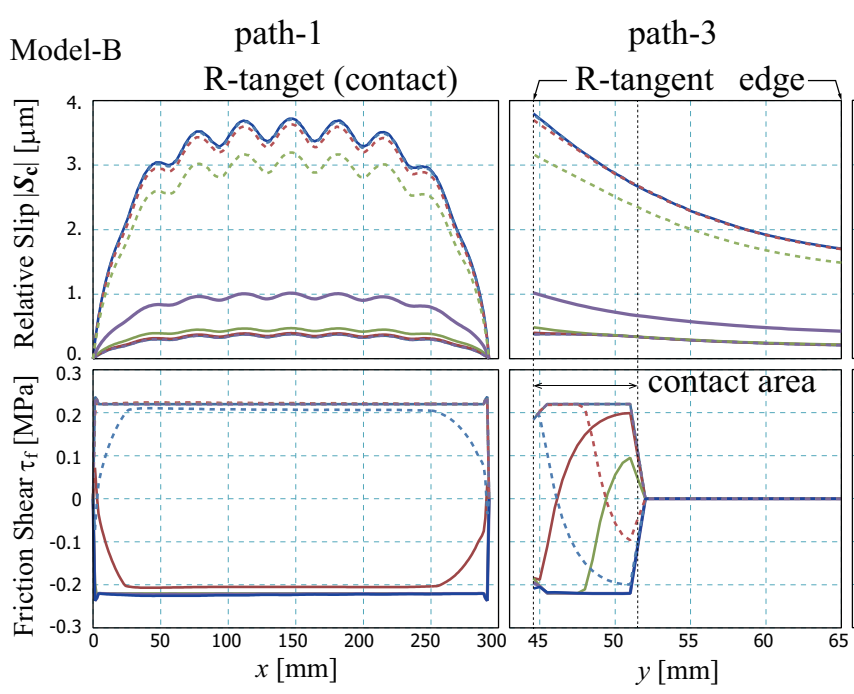

path-3
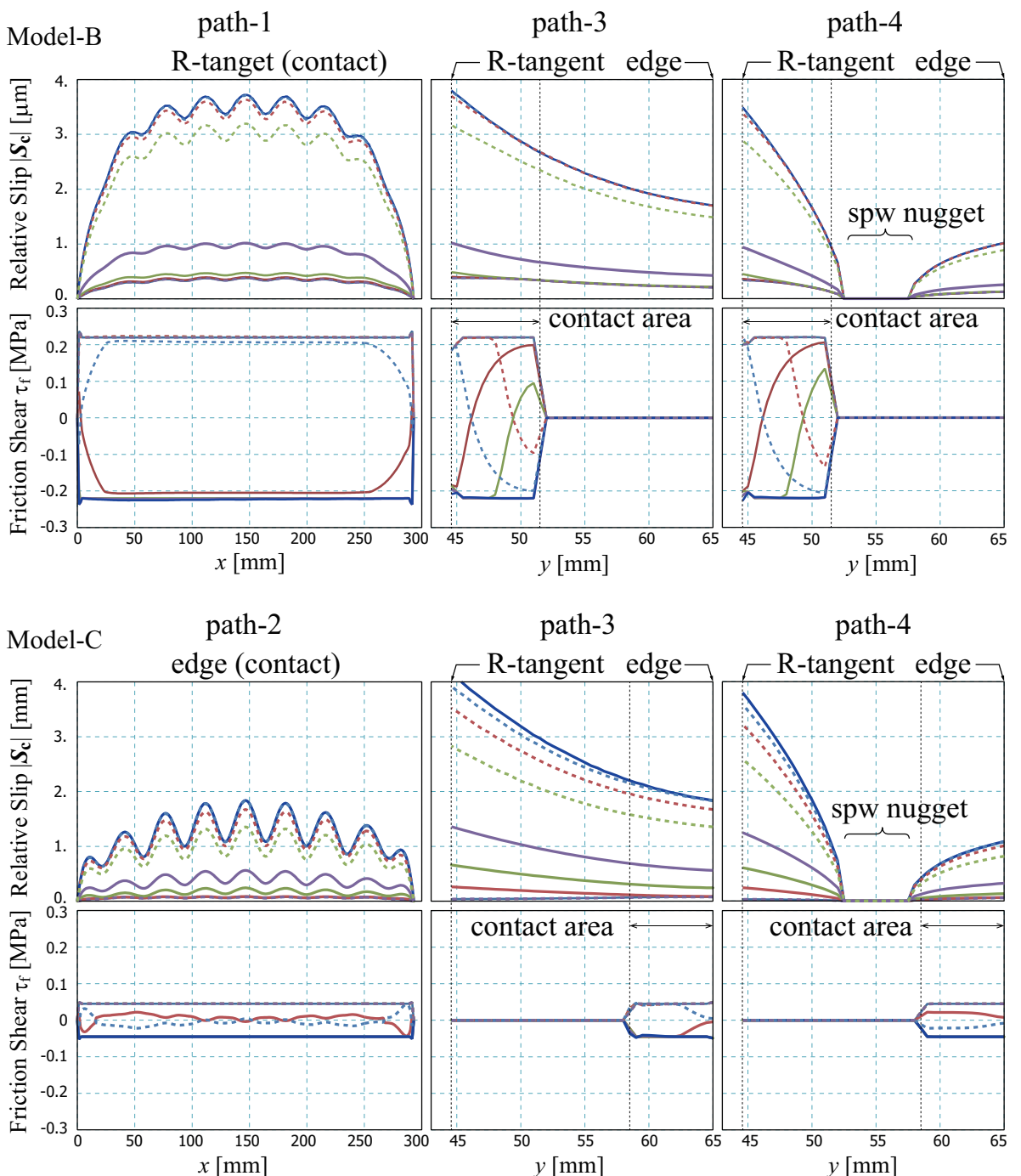

point-1

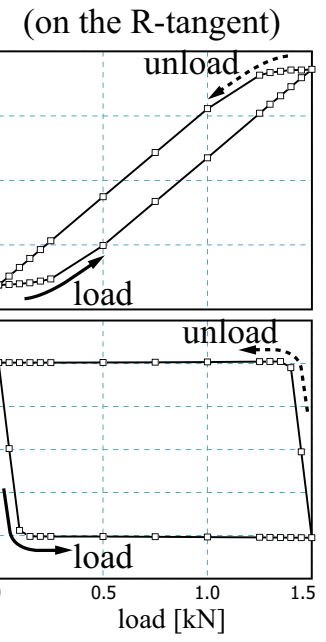

path-4
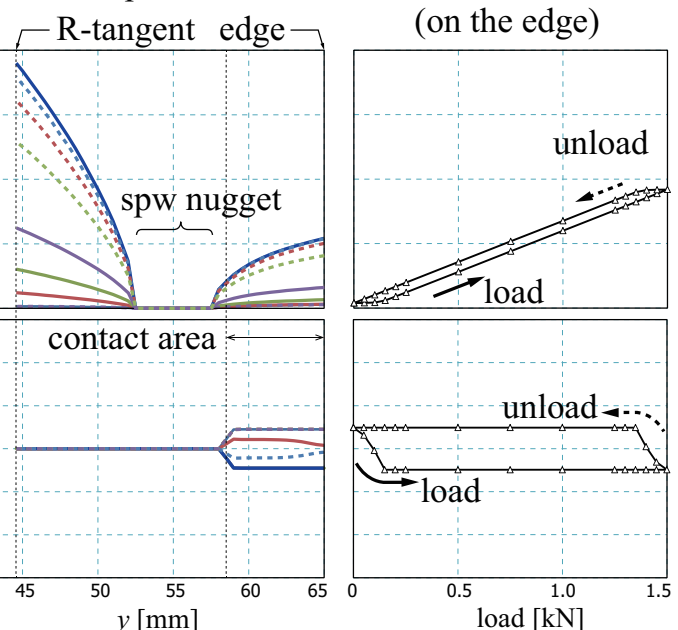

Fig. 11 the relative slip and friction shear on the flange surface of model-B (top two rows) and -C (bottom two rows). The graphs in the top and third row show the relative slip distribution in units of millimeter and second and bottom row show the friction shear distribution in units of megapascal. The graphs in left three columns are the distributions on path- 1 for model-B or path- 2 for model-C with respect to the $x$-coordinate in units of millimeter and path-3 and -4 with respect to the $y$-coordinate in units of millimeter. The solidlines show the distributions during loading and the dash-lines show during unloading. The graphs in the right column are the history of the relative slip and friction shear at the point- 1 (for model-B) or point- 2 (for model-C) with respect to the load in units of newton. The top figures show evaluating locations and the schematic image of relative slip. 
大きい。これが，相対滑りと摩擦力の内積の総和である摩擦損失もモデル B の方が大きくなる理由である.
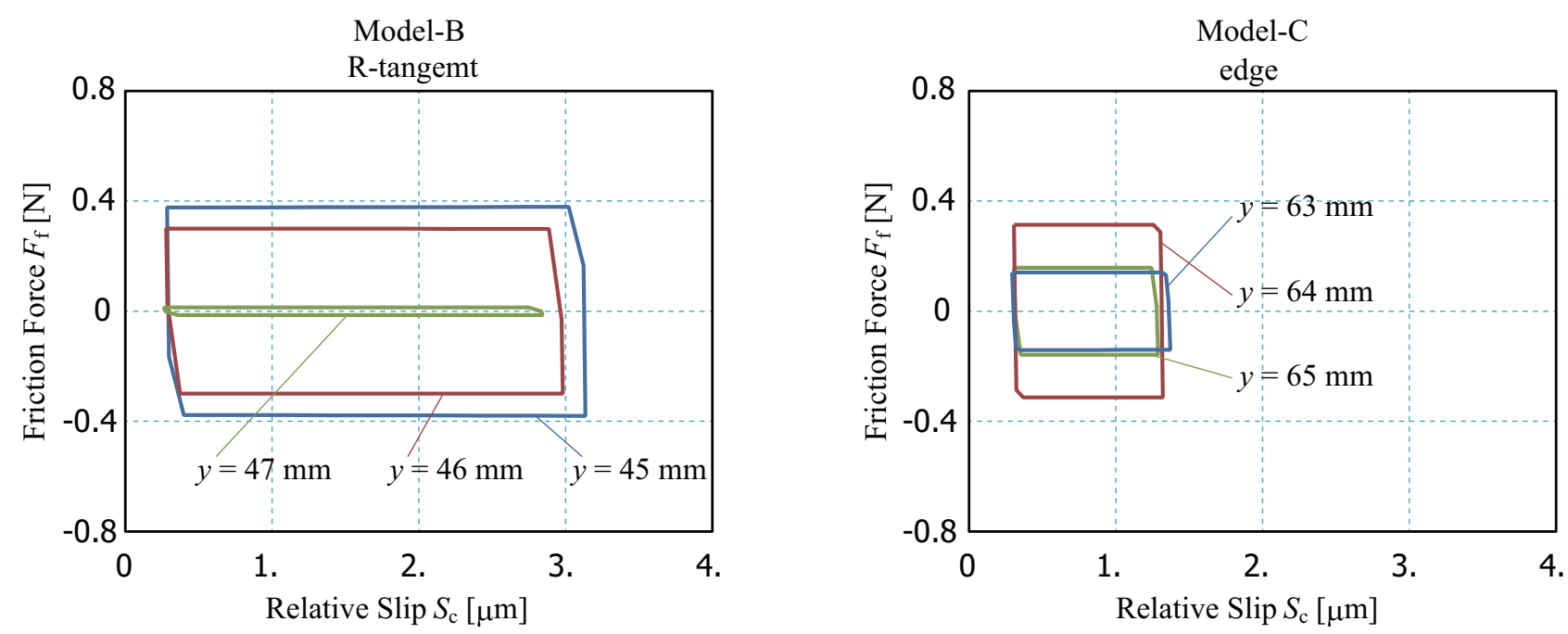

Fig. 12 the hysteresis loop in the relative slip and friction force diagram. The left and right figures show the loop of the nodes at the $x$-direction center in the contact region of hat- 1 of model-B and $-\mathrm{C}$ respectively. The horizontal axis is the relative slip in units of millimeter and the vertical axis is the friction force at the nodes in units of newton.

6. 結 言

鋼板をプレス成形し，溶接フランジにおける接触状態が異なるように組み立てた二種類のダブルハット部品を 対象に, 準静的, かつ，弾性の範囲においてせん断曲げ変形させたときの溶接フランジにおける接触摩擦を起因 とする損失エネルギ（摩擦損失エネルギ）を実験的に比較した。溶接フランジのエッジ付近を接触させた試験体 に比べ $\mathrm{R}$ 止まり付近を接触させた方が摩擦損失エネルギが大きくなる結果を得た．また，有限要素法を用い，接 触摩擦を考慮した数值解析は, 実験から得られる二種類の試験体における摩擦損失エネルギの差を再現するとと もに，フランジ面における摩擦現象について考察した。

接触領域を持つスポット溶接フランジにおける摩擦損失エネルギは，互いに接触する二つのフランジ面が相対 的に滑ることによって生じることが，数值解析より確認される. フランジ面の相対滑り量は相対的な拘束を受ける スポット溶接部近傍ではほぼゼロであり，スポット溶接部を挟む $\mathrm{R}$ 止まりおよびエッジに近づくほど大きくなり $\mathrm{R}$ 止まり側で最大になることが確認され，フランジ面エッジ近傍が強く接触するダブルハット部品に比べ $\mathrm{R}$ 止ま りで強く接触する方が高い摩擦損失となることが示される.さらに，せん断と曲げを独立に与えた数值解析から， フランジの相対滑りは，ダブルハット部品のせん断変形によって生じ，曲げ変形では生じないことが確認される.

今後，実走行時における車体にかかる荷重が今回の試験形態および数值解析の境界条件と比べ，どの程度の荷 重域に相当するのか，および，車体を構成する部品の溶接フランジの接触状態がどのような形態をなしているの かを明確にし，実際の自動車車体におけるヒステリシスに対する溶接フランジ摩擦の影響度を定量的に見積もる ことで，ドライバの官能評価である「剛性感」の改善指標を見出すことが期待できる.

\section{文献}

河内毅, 栗山幸久, 鈴木克幸, 構造体のヒステリシス評価と力学モデルの構築, 日本機械学会論文集, Vol. 83, No.

855 (2017), DOI: 10.1299/transjsme.17-00334.

熊本雅比古, 岡野恭久, 中島次郎, 赤松博道, 松本哲郎, 南部明宏, 福島英樹, 操安性能に影響する車体剛性非

線形性の解析，自動車技術会 2017 年秋季大会学術講演会講演予稿集，No. 157-17 (2017).

中谷弘能, 自動車の望ましい応答特性について - 四輪操舵車を用いた操安性の研究 -, 国際交通安全学会誌, Vol.

10, No. 2 (1984), pp. 62-70. 
椎葉太一, 小池亮太, 陳思予, フレキシブルマルチボディ車両モデルを用いたレーシングカートの運動特性評価,

日本機械学会論文集 C 編，Vol. 79，No. 806 (2013)，pp. 3291-3301.

嶋中常規, 中山伸之, 友貞賢二, 吉井群冶, 渡邊雅哉, 新型マツダアクセラのダイナミック性能, マツダ技報, No. 27 (2009), pp. 60-65.

須藤正俊, 野村伸吾, 溝口孝遠, 田中福輝, 高強度薄鋼板のスポット溶接性, 鉄と鋼, Vol. 68, No. 9 (1982), pp. 1411-1420.

武田健二, 白松広大, 岩田成樹, 寺口毅, 悪路走行入力における車体スポット溶接の疲労強度分析技術の開発, 自 動車技術会論文集, Vol. 45, No. 2 (2014), pp. 337-342.

武井一剛, 安田栄一, 土居俊一, 前田節雄, 車両のヨ一回転振動に対する人間の知覚感度, R\&D Review of Toyota CRDL, Vol. 36, No. 3 (2001), pp. 47-53.

冨岡敏憲，執行貴彦，望月浩孝，CX-9 の車体剛性の開発，マツダ技報，No. 25 (2007), pp. 61-64.

内山翔太, 瀬戸雅宏, 山部昌, ソーラーカーにおけるフレーム剛性が操縦安定性に及ぼす影響, 日本機械学会 第 24 回交通・物流部門大会 講演論文集 No. 15-63 (2015).

吉田裕一, 瀬戸厚司, 磯貝栄志, 潮田浩作, Bestien Weber, スプリングバックの影響を考慮したスポット溶接箱 型断面部材の疲労寿命評価, 塑性と加工, Vol. 621, No. 53 (2012), pp. 919-923.

\section{References}

Kawachi, T., Kuriyama, Y. and Suzuki, K., Evaluation and modeling of structural hysteresis, Transactions of the JSME (in Japanese), Vol. 83, No. 855 (2017), DOI: 10.1299/transjsme.17-00334.

Kumamoto, M., Okano, Y., Nakajima, J., Akamatsu, H., Matsumoto, T., Nanbu, A. and Fukushima, H., Evaluation of nonlinear body stiffness affecting vehicle handling performance, Proceedings of 2017 JSAE annual congress (autumn), No. 157-17 (2017) (in Japanese).

Nakatani, H., On Desirable response characteristics of vehicle - vehicle control studies with 4 wheel steering vehicle -, International Association of Traffic and Safety Sciences, Vol. 10, No. 2 (1984), pp. $62-70$ (in Japanese).

Shiiba, T., Koike, R. and Chen, S., Evaluations of racing kart behavior with flexible multibody dynamics, Transactions of the Japan Society of Mechanical Engineers, Series C, Vol. 79, No. 806 (2013), pp. 3291-3301 (in Japanese).

Shimanaka, T., Nakayama, N., Tomosada, K., Yoshii, G. and Watanabe, M., Dynamic performance of all-new Mazda Axela, Mazda technical review, No. 27 (2009), pp.60-65 (in Japanese).

Sudo, M., Nomura, S., Mizoguchi, T. and Tanaka, Y., Spot weldability of high strength steel sheets, Vol. 68, No. 9 (1982), pp. 1411-1420 (in Japanese).

Takeda, K., Shiramatsu, K., Iwata, S. and Teraguchi, T., Development of analytical methods for the fatigue life strength of spot-welding under road load conditions, Transactions of Society of Automotive Engineers of Japan, Vol. 45, No. 2 (2014), pp. 337-342 (in Japanese).

Takei, K., Yasuda, E., Doi, S. and Maeda, S., Human sensitivity for vehicle yaw-motion, R\&D Review of Toyota CRDL, Vol. 36, No. 3 (2001), pp. 47-53 (in Japanese).

Tomioka, T., Shigyou, T. and Mochizuki, H., Body rigidity for CX-9, Mazda technical review, No. 25 (2007), pp. 61-64 (in Japanese).

Uchiyama, S., Seto, M. and Yamabe, M., Influence of frame stiffness on handling stability in solar vehicle, TRANSLOG2015, No. 15-63 (2015) (in Japanese).

Yoshida, Y., Seto, Isogai, E., Ushioda, K. and Weber, B., Fatigue life prediction in spot welded rectangular section members under springback effect, Journal of the Japan Society for Technology of Plasticity, Vol. 621, No. 53 (2012), pp. 919-923 (in Japanese). 